\title{
MANUALS OF FRENCH WITH REFERENCE TO OVERSEAS TRAINING
}

\section{II}

In continuation of the notes which appeared in the March number of this JourNaL, the writer is now able todiscuss a second group of manuals of military French. As previously indicated, information regarding other publications of similar character will be welcomed, with a view to the preparation of a third review in case there should be sufficient additional material to warrant it.

Two small handbooks which have had a wide circulation among men in army camps, are issued by the National Security League and by the Y.M.C.A. The former, entitled English-French Handbook, ${ }^{1}$ was prepared by Professor C. A. Downer. More than 200,000 copies have been supplied free to men in the national service. After a brief explanation of the pronunciation, there follow words and phrases for ordinary intercourse (pp. 10-47) and classified lists of military terms (pp. 48-63). Three parallel columns give the English, the French equivalent, and the pronunciation, the latter being indicated by phonetic symbols which are easy to read and sufficiently accurate for the purpose. This little book is evidently intended for self-study and reference as well as for use with classes; within its obvious limitations-there is no grammar-it is well adapted for practical use.

The still smaller booklet of the Y. M. C. A., ${ }^{2}$ said to be more widely used in the camps than any other text-book of French, is the work of a committee of New York teachers. It is intended "simply to give a good start towards hearing, pronouncing, understanding and speaking French." It emphasizes "practice rather than explanation," and assumes on the part of the teacher nothing more than a certain command of the spoken language. In the directions for pronunciation (pp. 15-25) it is fortunate that "nearEnglish equivalents have been shunned as futile and misleading." We note, however, that many Americans give the same sound to the vowel in "pat" and in "calm," here used (p. I7) to explain two

'English-French Handbook for the use of United States Soldiers. New York, National Security League, 3 I Pine St.; pp. 64. Price, Io cents.

${ }^{2}$ W. L. Hervey and L. A. Wilkins, Premier Secours: First Aid in learning French. New York, Association Press, 124 East 28th St., 1917; pp. 120. Price, 20 cents. 
different French sounds. Dialogues with the English and French in parallel columns, without indication of pronunciation and without any grammatical information, make up the bulk of the book. Conscientious drill in this material under a competent teacher, according to the model given in the first lesson, would doubtless result in some conversational facility; but it is to be regretted that the editors did not take their task a little more seriously, and give our soldiers credit for a little more earnestness and intelligence. Several of the books already reviewed combine with effective conversational material the elements of grammar. On the other hand, this First Aid is too fragmentary, and in many places too trivial, to be of use as a phrase-book or vocabulary. The introduction of a lesson on "locutions familières" is decidedly questionable. As Colonel Willcox says in his Dictionary (p. 583 ; see below), there is only one safe general rule for our officers and men in regard to French slang, especially military slang: avoid it.

The Military Manual ${ }^{3}$ by Mr. Bond and Miss Norman of the University of Texas, grew out of material assembled for use at Fort Bliss, E1 Paso, in July, I9I7; it has already seen service with over 4000 men. Its present form, as Mr. Bond writes, shows the limitations of a local printer; the system of phonetic symbols, for instance, is more or less a makeshift. The heavy-face letters used to indicate the nasal vowels are difficult to distinguish-a disadvantage, by the way, which they share with the italic letters used as symbols of the nasals in the Giese-Cerf and Wilkins-Coleman manuals. Far better, not only because they correspond to the symbols of the International Phonetic Association, but because they are easier to distinguish, are the vowels with a superposed mark like the tilde, used in Professor Downer's Handbook, in the Nitze-Wilkins Handbook of French Phonetics, in C. F. Martin's Essentials of French Pronunciation (Boston, Heath, 1918 ), and in several grammars. The objection to Mr. Bond's symbols is not that they are inaccurate, but simply that they are difficult to read. His warning (p. 9) against pronouncing an $n$ or $m$ with the nasal vowel is timely, in view of the misleading $u n g, u n h$ or $n$ with a mark cver it, used as symbols in certain books. It should be noted that the English word pant would be better than ant (p. 8) as an example to explain

${ }^{3}$ O. F. Bond and H. L. Norman, Military Manual of Elementary French, Austin, Texas, Steck, 1918; pp. 79. 
the nasal in, since ant is so often pronounced to rhyme with haunt (given here as an example of the nasal on). The attitude of the authors of the Manual in regard to teaching pronunciation is judicious: sound-symbols are a satisfactory guide only when the sounds themselves are mastered; the learner must first hear and then imitate patiently a correct pronunciation. The simplification is in general not carried too far under the circumstances. It is wrong, however, to pronounce oui and $u i$ alike, and to sound an $l$ in juillet. The book is arranged c $\rightarrow$ a different plan from the other manuals; part I consists of 26 lessons, each having a paragraph of French text, exercises for drill, and word-lists headed "Information;" also references to part II, a concise systematic grammar. The book ends with a French-English vocabulary in which the pronunciation is indicated for every word. Since the pages are 8 by 5 inches in size, and closely printed, there is more material than in many books that look larger. Useful military expressions are included. There is, however, altogether too much emphasis on slang expressions, such as artiflot for "aviator" and griller des sèches for "smoke cigarettes." But the pamphlet has enough good features to merit being reprinted, as the authors propose, in more attractive and permanent form.

The Soldier's Language Manual ${ }^{4}$ consists of two parts, evidently first printed in England, and undated. The first part, which is new, contains classified lists of military terms in English, French and German, printed in parallel columns on the right-hand pages, with occasional notes on the left-hand pages, and an English index at the end. The author states that his object is "first and foremost, to suggest to the student the value of thinking from French into German, and vice versa." It is safe to say that this object will not appeal very strongly to the average young American; but, like other word-lists, this one may prove useful. The section on aviation (pp. 57-67) makes the extraordinary blunder of translating avion as "aviator." The second part, with separate title-page and pagination, is "French self-taught with phonetic pronunciation, by C. A. Thimm, enlarged by T. de Marney." This work of

'E. G. A. Beckwith, The Soldier's Language Manual, military expressions in English, French and German; including a complete course of instruction for learning French, by C. A. Thimm. Philadelphia, D. McKay; pp. $72+120$. Price, 50 cents. 
uncertain age contains long lists of words with English, French, and the alleged pronunciation in parallel columns, and a few pages of grammar. We are told to call a dog ung sheeang; entendre is aungtaungdr. Equally objectionable in its treatment of the pronunciation is Gallichan's little conversation book, ${ }^{5}$ in which words and phrases thought likely to be useful to soldiers in ordinary intercourse are grouped according to subject; the English having an interlinear French translation and its "pronunciation." The very first sentence, "There is the gangway," is incorrectly translated, for passavant does not mean "gangway;" the pronunciation is: "vwa-see ler par-sa-von." Faim is to be pronounced "fam." A much better phrase-book is the one by Jean A. Picard, ${ }^{6}$ author of the more technical Military Manual previously noticed. The words and phrases are arranged to meet the ordinary requirements of the American soldier, who, as Picard points out, will as a rule need to use French when at the rear rather than when on active duty in the ranks. If the grammar and pronunciation were to be mentioned at all, they might have received fuller treatment. Another phrase-book is issued for free distribution as an advertisement of a well-known tooth-paste. ${ }^{7}$ Rules are given for forming German sounds, but not for French; the phrases are well selected, but the value of the indications of pronunciation may be judged from: "mo-ance" for moins, "jay fraud" for $j$ 'ai froid, "av-vay voo voo" for avez-vous vu.

Excellent for its vocabularies of military terms and other technical information is the Vade-mecum of Eugène Plumon. ${ }^{8}$ It was originally written in 1914 for the use of interpreters with the British forces in France; in the edition printed in America the portion relating specifically to the British army organization is

'W. M. Gallichan, The Soldier's English and French Conversation Book. Philadelphia, Lippincott, I917; pp. 128. Price, 35 cents.

'Jean A. Picard, Cortina French-English Soldier's Handbook. New York, Cortina Academy of Languages, I9I7; pp. 95. Price, 50 cents. The same author has also published a Cortina French-English Red Cross Instructor (price, 50 cents) and a Cortina French-English Military Diclionary (price, 35 cents.)

7F. N. Maude and F. Scudamore, "Parley voo booklet," practical French and German phrases and how to pronounce them. New Haven, The Kolynos Co.; pp. 39.

Eugène Plumon, Vade-mecum for Officers and Interpreters in the present campaign; French and English technical and military terms. New and revised edition. Paris and London, Hachette; New York, Brentano's, 1917; pp. 164. Price, 75 cents. 
omitted, and the number of pages, 233 in the fourth English edition is thus reduced to 164 . A working knowledge of French is assumed. Special vocabularies are given in the order in which they will be needed from the landing in France to the camp and the battlefield, with attention to every aspect of military life, such as organization of the army, reading of maps, equipment, transportation, supply, medical service, German phrases for questioning prisoners, etc. A vast amount of information is given in compact form.

A book which attracts notice first by the profusion of red ink and empty spaces, and secondly on account of the extravagant claims put forth by the publishers, is the Oral French Method of Mlle. Alice Blum. ${ }^{*}$ What ordinary academic methods require years to teach, this method is said to impart in a short time. The author has had twenty years' experience in teaching French to Americans, and during the last year is said to have instructed hundreds of our soldiers with such effect that they readily pass as born Frenchmen. French, according to her preface, is "the most logical of languages," but logic is not a quality of her book. Doubtless with a class her enthusiasm, evident even on the printed page, would be contagious, and her originality would make a strong impression; but it is a question whether other teachers could succeed with this method. The naivete of the book is disconcerting; it has errors and inconsistences, and leaves much to be supplied and explained by the teacher. Nevertheless, it is interesting in many ways. Its aim may be conservatively stated as an attempt to give confidence in pronouncing French words and in forming phrases. It is in no sense a grammar. It treats French spelling to some extent, but is fragmentary and disjointed, paying no attention to connected reading. The fundamental principle is apparently to have the class in chorus imitate the words uttered by the teacher, "with the joy and pride of exteriorizing at once the new thought." Under this unfortunate expression is concealed a useful idea. Many teachers may consider with profit some of the devices used for concentrating the mind of the student on certain definite points. Other devices are too individual for general use. For instance, the vowels "incorrectly called nasal" (p. 3) are here nicknamed "down-

9Alice Blum, Oral French Method, New York, G. H. Doran Co., [1917]; pp. xiv, 337, with Supplement, pp. 32. Price, \$2. 
stair-sounds," on the ground that they come from the abdomen, and later (p. 24) they are called consonant-sounds. All other vowels are "up-stair sounds." The six syllables $b a$ be be bi bo bu are to be intoned as half of an alexandrine (the $b u$ being printed in red to indicate the césure, i. e. emphasis!). Bou and boi are added as "outsiders" (pp. I 7-9, 64). An excellent device is used to indicate silent consonants - a red line printed obliquely across the letter. In fact, the two colors of ink are made use of in various ingenious ways. Extremely good are the photographs showing the position of the lips in pronouncing different sounds. A large vocabulary is employed, with much repetition and drill. A serious fault is the total omission of the pronouns and verb-forms of the second person singular, very frequently used, of course, in the army. While intended for soldiers, the book is not in the least military; but the Supplement gives alternative lists of military words to be used instead of certain pages. It also includes some Parisian slang, which "every American may use but must understand," e. g. raseur, "stick in the mud." For midinette, "young working-girl," this remarkable etymology is given: "midi = noon; dinette $=$ sham-dinner." This Supplement is even more profuse than the main book in blank spaces; both could have been printed in a fourth of the space. At present the book is unnecessarily bulky.

As a reminder that we have not been in the war so long as some others, comes The Canadian Soldier's Manual, ${ }^{10}$ published in 1915 in 'Toronto. It is divided into three parts, French pronunciation and grammar, pp. I-I8; German pronunciation and grammar, pp. I9-4I; Vocabulary, pp. 42-78,-arranged alphabetically in English with French and German equivalents. The explanations are clear and accurate. Useful phrases are given. It is noticeable that more space is given to German than to French.

At West Point ${ }^{1}$ by two of the professors in the Military Academy consists of a French text in short sections, with questions in French and in English and composition exercises. Grammatical rules are suggested without being explained. The book is not intended for beginners; it is adapted for grammar review, conversational prac-

${ }^{10}$ The Canadian Soldier's Manual for French and German. Prepared by Professors of the University of Toronto. Toronto, Camp Chaplain's Office, [191 5]; pp. 78. Price, 25 cents.

'C. F. Martin and G. M. Russell, At West Point. A practical course in speaking and writing French. Boston, Heath, pp. vii, 242. Price, $\$ \mathbf{1} .40$. 
tice and composition. The text gives a continuous account of the experiences of two cadets at West Point; it will arouse interest in all classes of students by the information given about military training. The two vocabularies are carefully made. Several illustrations add to the attractive appearance of the book. For reading-matter dealing with military affairs, two little volumes in the Oxford French Plain Texts may be cordially recommended. They are printed without notes or vocabulary. Advanced classes may turn to the series Ecrivains Français pendant la Guerre, published by the Librairie Larousse, and handled in this country by the Oxford University Press. ${ }^{2}$ Particularly interesting are the selections from writings of Ernest Lavisse and Maurice Barrès ${ }^{3}$ dealing with various aspects of the war.

There remain to be mentioned the dictionaries. Of foremost importance is the French-English Military Technical Dictionary by Colonel Willcox, ${ }^{4}$ a book which should be available not only in every camp, but in every college and public library. First published by the War Department in I 899, it had of course become out of date by reason of the recent development of military science, and in particular of aviation. In I 9 I 7 it seemed best, however, to reprint the original work, of 492 closely printed double-column pages, and to add a supplement, rather than take the time necessary to incorporate the new material in the body of the book. The supplement consists of over 80 pages, and of course some slight inconvenience results from this arrangement After the Government had issued the new edition in the fall of 1917 , the publication of the Dictionary in the regular book-trade was taken over by the firm of Harper \& Brothers, and two more pages of errata and addenda were added. This work is not only authoritative for strictly military information, but useful for other purposes as well, since it includes much that is not exclusively military. The defini-

${ }^{2}$ Franc-Nohain and Delay, Extraits de l'histoire anecdoique de la guerre. Selected and edited by C. H. Clarke. (I) Paris menacé, Paris sauvé; pp. 48. (2) L'Armée française sur le front; pp. 48. Oxford University Press, 1917. Price each, 20 cents.

(1) E. Lavisse, Pages choisies. Préface de C. Pfister; pp. I22. (2) M. Barrès, Pages choisies. Préface de F. Baldensperger; pp. 149. Price each, 25 cents in paper, 75 cents in cloth.

${ }^{4} \mathrm{C}$. De W. Wilicox, A French-English Military Technical Dictionary with a supplement containing recent military and lechnical terms. New York, Harper s [1917]; pp. xv, 584. Price, $\$ 4$. 
tions are accurate and inclusive, and cover phrases as well as single words. The pronunciation is not indicated The lists of abbreviations are convenient but not complete (e. g. the following are not found: C. I. D., D. T. M. A., R. V. F., S. S. A.). It is worth while to quote from the preface these words: "With French alone an officer can keep abreast of his profession almost as well as though he had at his command all the other foreign languages whose military literatures are important in a professional point of view."

On a much smaller scale, the Soldier's Service Dictionary ${ }^{5}$ bound in khaki and of a convenient size for the pocket, may be recommended as an English-French vocabulary. It contains some ro,000 military and conversational words alphabetically arranged and carefully defined, and will unquestionably prove extremely useful in enabling our troops to express themselves in French, provided they already have some knowldge of the language; indeed, it could be used even without any conversational ability, by pointing out words and phrases as needed. The pronunciation is indicated by an accurate system of phonetics. A few grammatical notes are appended.

The Glossary of Aviation Terms, ${ }^{6}$ by two expert aviators, one French and one American, is simply what its name indicates, a series of word-lists, English-French and French-English, without explanation. The numerous diagrams of aeroplanes and their parts, with terminology in both languages, will evidently be useful even without regard to the language element. The book will certainly facilitate intercouse between aviators and mechanics speaking different languages.

In conclusion, the writer desires to express his hearty agreement with the views of Professor Downer in his excellent article in the March number of this JOURNAL.

University of Illinois.

Kenneth McKenzie.

\footnotetext{
'Frank H. Vizetelly, The Soldier's Service Dictionary of English and French Terms, New York, Funk \& Wagnalls, r9i7; pp. xii, I88. Price, \$1.

${ }^{6}$ Victor W. Pagé and Paul Montariol, Glossary of Aviation Terms. New York N. W. Henley Publishing Co., 1917; pp. 94. Price, \$1.
} 